\title{
The COVID-19 Pandemic: Global Asymmetries and Challenges for the Future of Health
}

\author{
Nísia Trindade Lima*; Carlos Grabois Gadelha ${ }^{*}$
}

The coronavirus disease 2019 (COVID-19) pandemic reveals economic, social, and environmental trends that have been present since the last two decades, and it is characterized as a new phenomenon that qualitatively alters contemporary global and national dilemmas - not only because it was caused by a hitherto unknown virus, but by the magnitude of the crisis and the transformations that shape the lifeworld. It marks a disruptive and threatening historical period in the face of the foundations of modern sociability built during the post-war period.

Social and economic inequality between countries, territories, and population groups has increased during the pandemic. Its impacts are unevenly distributed, revealing the interface between the biological, economic, and social worlds. There is a threat of a humanitarian crisis due to the concrete differences between those who have full access to products, services, and health and those who can be left behind. In Latin America alone, the income of more than 30 million people has fallen below the poverty threshold less than a year after the arrival of the pandemic to the continent (1).

In terms of international relations, the pandemic highlights the tension between a vision of global health and the interests of the nation states and regional blocs. Vulnerability is observed even in developed countries, manifested in the lack of fundamental health items such as ventilators, essential medicines used in treatment, and even more basic items such as masks and personal protective equipment for health providers. Within the scope of the relationship between the nation states, the dispute over health products, with the imposition of trade barriers by more developed countries that could lead a solidarity action in health, has resulted in a limitation of access, generating global inequity. At present, limiting the supply of vaccines to less developed countries and vulnerable populations undermines the impact of essential mechanisms, such as the COVAX Facility [the initiative led by World Health Organization (WHO), Global Alliance for Vaccines and Immunization
(GAVI) and the Coalition for Epidemic Preparedness Innovations (CEPI)], which is aimed at ensuring equal access to immunization.

In Brazil, this debate has motivated the strengthening of an approach developed at the Oswaldo Cruz Foundation (Fiocruz) - the main health science, technology and innovation institution in Latin America - in the last decades, which conceives health as development, understood in the concept of the Health Economic-Industrial Complex (HEIC) (2). A set of public policies for partnerships between the state and the private industries was established, including the strengthening of local production of state-of-the-art diagnostic tests, drugs, and vaccines. This conception shows that the production, science, technology, and local innovation bases are essential to give economic sustainability to the universal Brazilian health system (The Unified Health System - SUS), also favoring global cooperation guided by the solidary exchange of technologies. This virtuous link in the relationship between local technological training in the least developed countries and global cooperation has been demonstrated by the experience of Brazil's cooperation with Africa in the area of vaccines and medicines, including the transfer of technological and productive capacity and not just the sale and the supply of products.

The economic, production, and innovation basis in health must be seen as an essential element for national health systems and for global health, as evidenced in the COVID-19 pandemic, which demonstrated that primary healthcare actions, epidemiological surveillance, and hospital treatment depended on the availability of health products and services, without which the objectives of universal and equitable access could not be achieved (2). With this view, as emphasized in a recent publication in the China CDC Weekly, the availability of critical health products and services is also seen as an essential factor in health national security (3).

The integration of the social, economic, and environmental dimensions of development is, 
therefore, essential to enable a healthy life, considering that health is understood as quality of life. Once again, the COVID-19 pandemic shows that the countries best placed to face it were those that managed to integrate the organization of health systems, social protection, the provision of basic services, programs to mitigate the effects of the economic crisis, the policies of social cohesion and community resilience, and a strong reinforcement of the responsiveness of the systems of science, technology, and innovation in health.

Based on this context, it is possible to show the major challenges that must be faced so that the future of health contributes to a more equitable and fairer world guided by sustainable development:

1) The strengthening of universal health systems, with strong evidence in both the international and Brazilian experiences in that public health and collective action are essential for the resilience of the countries and preparedness to face future pandemics and health issues, including both communicable and chronic diseases (4-6).

2) The core relevance of strengthening science, technology, and innovation for a new vision of public health in the knowledge society. It becomes necessary to face the mother of all inequalities: the inequality of knowledge, innovation, and the production base. In addition, without a more symmetrical distribution of productive and innovation capacities, the growing concentration and monopolization of health will render national and global responses based on universality and equity unfeasible ( 7 ).

3) The global effort to guide the economic, productive, and technological base in health, from different countries with different levels of development, towards social and environmental needs. The demands of society and the sustainability of the planet must guide all public policies and be integrated into the principle that the ultimate meaning of development is the promotion of quality of life and

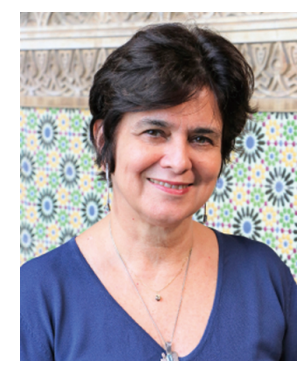

Nísia Trindade Lima, PhD

President of the Oswaldo Cruz Foundation - Fiocruz environmental preservation. The 4th technological revolution presents the risk of rupture and structural reproduction of inequalities, leading to work and people being in a precarious situation. However, it also represents an enormous opportunity to place the world of artifacts and technology at the service of the greater goals of society and the planet.

Dealing with these challenges requires the definition of a strategic agenda of commitments that reduce asymmetries between countries and consider the global vulnerability to face the unequal conditions of response to health emergencies as revealed by the COVID-19 pandemic.

doi: $10.46234 / \mathrm{ccdcw} 2021.039$

\# Corresponding authors: Nísia Trindade Lima, nisia.lima@fiocruz.br; Carlos Grabois Gadelha, carlos.gadelha@fiocruz.br.

Submitted: January 30, 2021; Accepted: February 02, 2021

\section{REFERENCES}

1. Lima NT, Buss PM, Paes-Sousa R. COVID-19 pandemic: a health and humanitarian crisis. Cad Saúde Pública 2020;36(7):e00177020. http://dx.doi.org/10.1590/0102-311x00177020.

2. Gadelha CAG, Temporão JG. Development, innovation and health: the theoretical and political perspective of the Health Economic-Industrial Complex. Ciênc Saúde Coletiva 2018;23(6):1891-902. http://dx.doi.org/10.1590/1413-81232018236.06482018.

3. Wang J, Shi XM. Harmonizing the COVID-19 pandemic response with economic and social recovery. China CDC Wkly 2020;2(36):704 - 7 . http://dx.doi.org/10.46234/ccdcw2020.171

4. Frieden T. A strong public health system: essential for health and economic progress. China CDC Wkly 2020;2(7):128-30. http://dx.doi.org/10.46234/ccdcw2020.035.

5. Wu XF, Ye YQ. A public health perspective on preventing and controlling the spread of coronavirus disease 2019. China CDC Wkly 2020;2(14):237 - 40. http://dx.doi.org/10.46234/ccdcw2020.060.

6. Castro MC, Massuda A, Almeida G, Menezes-Filho NA, Andrade MV, de Souza Noronha KVM, et al. Brazil's unified health system: the first 30 years and prospects for the future. Lancet 2019;394(10195):345 - 56. http://dx.doi.org/10.1016/S0140-6736(19)31243-7.

7. Gadelha CAG, Nascimento MAC, Braga PSC, Cesário BB. Global technological transformations and asymmetries: development strategy and structural challenges for the Unified Health System. Ciênc Saúde Coletiva 2018;23(7):2119 - 32. http://dx.doi.org/10.1590/1413-81232 018237.09452018 .

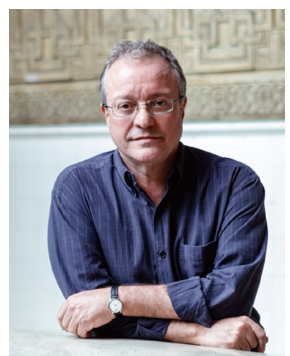

Carlos Grabois Gadelha, PhD

Coordinator of Prospecting Activities of the Presidency of Fiocruz, Brazil 